\title{
OPTIMASI PRODUKSI MEUBEL MENGGUNAKAN MODEL PEMROGRAMAN LINEAR
}

\author{
Hendy Tannady \\ Email : htannady@bundamulia.ac.id
}

\section{Penulis}

Hendy Tannady adalah dosen di Universitas Bunda Mulia dalam bidang Manajemen Operasional (simulasi, antrian dan perancangan fasilitas)

\section{Abstrak}

Permasalahan sumber daya yang terbatas memang sering kali dimiliki oleh banyak perusahaan, dan itu sangat menyita konsentrasi dan fokus dari perusahaan dalam menentukan strategi produksi, khususnya dalam menentukan jumlah produksi. Penelitian ini membahas aplikasi dari Pemrograman Linier untuk memecahkan permasalahan optimasi produksi. Penelitian diadakan di sebuah perusahaan mebel, ada berbagai fungsi kendala yang dijumpai perusahaan, yakni : $1.15 \mathrm{X}_{1}+0.98 \mathrm{X}_{2}+0.56 \mathrm{X}_{3}+0.40 \mathrm{X}_{4}+0.16 \mathrm{X}_{5}$ $\leq 376$ (Fungsi bahan baku) dan $3.25 \mathrm{X}_{1}+2.82 \mathrm{X}_{2}+1.56 \mathrm{X}_{3}+1.23 \mathrm{X}_{4}+0.85 \mathrm{X}_{5} \leq 192$ (Fungsi jam kerja), sedangkan fungsi obyektif adalah $Z_{\max }=1245 \mathrm{X}_{1}+1055 \mathrm{X}_{2}+750 \mathrm{X}_{3}+$ $610 X_{4}+535 X_{5}$, hasil dari penelitian adalah dengan keterbatasan yang dimiliki perusahaan, sebaiknya perusahaan hanya memproduksi Tipe Lemari 1 Tingkat Tinggi $\left(\mathrm{X}_{5}\right)$ sebanyak 225 unit lemari/bulan, dan akibat dari produksi ini perusahaan akan menerima keuntungan sebesar Rp 120.847.000.

\section{Kata Kunci}

Sumber daya, pemrograman linier, optimasi.

\section{PENDAHULUAN}

Di dalam pelaksanaan produksi, sumber daya baik itu manusia, mesin dan material harus dimaknai sebagai sumber daya yang terbatas, tidak jarang organisasi tidak mempertimbangkan dan memperhitungkan keterbatasan sumber daya yang mereka miliki ketika organisasi menyusun sebuah perencanaan produksi. Namun dengan melakukan 
optimalisasi sumber daya bukan tidak mungkin keuntungan maksimal dapat diperoleh. Aminudin (2005) di dalam bukunya berjudul Prinsip-Prinsip Riset Operasi mengemukakan bahwa organisasi harus membuat aturan tentang pengalokasian sumber dayanya dan tidak ada organisasi yang beroperasi permanen dengan sumber daya yang tidak terbatas.

Penelitian ini mengangkat topik tentang penerapan pemrograman linier dalam menentukan berapa jumlah unit yang harus diproduksi oleh industri meubel yang berlokasi di Tangerang. Industri meubel memproduksi 5 jenis lemari dengan bahan baku dasar yang sama yakni kayu. Produk yang dihasilkan antara lain : Lemari 2 Pintu Lebar, Lemari 2 Pintu Ramping, Lemari 3 tingkat terbuka, Lemari 3 tingkat terbuka ramping, dan Lemari 1 tingkat tinggi. Lima jenis lemari ini adalah jenis lemari yang paling sering mendapat pesanan dari customer dalam jumlah besar. Sehingga untuk mengantisipasi besarnya permintaan tersebut, perusahaan mendirikan 1 lokasi produksi khusus bagi 5 jenis lemari. Hal yang ditemui di lokasi pabrik yang juga berfungsi sebagai gudang adalah menumpuknya bahan baku dan produk jadi yang diakibatkan over production dan tidak terolahnya bahan baku akibat produk yang menggunakan sengaja diproduksi lebih sedikit. Tentunya situasi ini merupakan dampak dari tidak optimalnya alokasi penggunaan bahan baku.

Tujuan dari penelitian adalah menentukan jumlah produksi setiap jenis lemari yang optimum, tentu organisasi ingin memproduksi sebanyak-banyaknya, namun keterbatasan sumber daya memaksa adanya alokasi yang optimum. Pemilihan penyelesaian masalah dengan pemrograman linier adalah karena berdasarkan pembahasan oleh banyak peneliti, pemrograman linier telah terbukti mampu menyelesaikan permasalahan optimasi dari waktu ke waktu dan digunakan pada berbagai situasional problem, Merlyana dan Abbas (2008) pernah melakukan pembahasan penggunaan program linear untuk memaksimumkan keuntungan, Robert T. H dkk (2008) melakukan analisa produksi pada PT. MAST dengan program linera, Purnama dkk (2010) tentang optimasi produksi tahu dengan jenis tahu goreng dan tahu putih, Affandi (2011) Aplikasi pada permainan non kooperatif, J.B Evans dkk (2003) yang membahas aplikasinya untuk mendeteksi dan menemukan asteroid yang dekat dengan bumi dan M Petrik dan S Zilberstein (2011) yang 
menulis aplikasi linear programming pada manajemen sumber daya. Di dalam bukunya yang berjudul Riset Operasi, Mulyono (2007) juga menambahkan bahwa program linear juga berkaitan dengan penjelasan suatu dunia nyata sebagai suatu model matematika yang terdiri atas sebuah fungsi tujuan linier dan sistem kendala linier.

Guna mendukung hasil dari keputusan akhir, tentulah membutuhkan berbagai data yang akan dipergunakan dalam tahap pembahasan dan olah data. Berbagai data yang disajikan antara lain : Tabel 1 memuat data tentang laba bersih dari setiap produk, Tabel 2 yang memperlihatkan Data penggunaan bahan kayu untuk memproduksi setiap lemari per $\mathrm{m}^{3}$ dan Tabel 3 yang berisi data jumlah tenaga kerja dalam membuat 1 produk lemari per jam.

\section{PEMROGRAMAN LINEAR}

Dimyati (2008) didalam bukunya menyatakan bahwa pemrograman linier merupakan cara untuk menyelesaikan permasalahan sumber daya yang terbatas diantara beberapa aktivitas yang bersaing dengan cara yang mungkin untuk dilakukan. Program linier adalah salah satu teknik pada riset operasi yang paling umum digunakan dan diketahui dengan baik, juga merupakan metode matematika dalam mengalokasikan sumberdaya yang langka untuk mencapai tujuan yakni memaksimumkan keuntungan atau meminimumkan biaya atau keduanya (Mulyono, 2007). Pemrograman linier juga didefinisikan sebagai permasalahan dalam memilih variabel riil untuk memaksimum-kan atau meminimum-kan fungsi tujuan dengan batasan linear pada variabelnya, dimana fungsi maksimum dan minimum disebut obyektif (Affandi, 2011). Susanto dkk (2006) juga mengutarakan bahwa pemrograman linier memiliki sebuah fungsi obyektif dan satu atau lebih kendala. Program linear juga dianggap mampu mewakili situasi pada dunia nyata dengan melibatkan banyak parameter dengan nilai yang ditentukan oleh ahli (Kumar \& Kaur, 2011).

Pemrograman linier pertama kali dikemukakan oleh George Dantzig (Susanto,2006 ; Mulyono,2007) pada tahun 1947 (Susanto,2006). Winston (2003) di dalam bukunya pernah mengemukakan bahwa dalam sebuah survey yang dilakukan oleh Fortune 500 kepada beberapa perusahaan memperlihatkan bahwa $85 \%$ dari responden menggunakan pemrograman linear. Metode itu tersusun atas dua komponen utama yakni fungsi objektif dan kendala, fungsi objektif berhubungan dengan tujuan yang hendak dicapai dan akan 
dimaksimumkan bila menyatakan keuntungan dan akan diminimumkan bila menyatakan biaya (Susanto, 2006).

\section{Produksi dan Profit}

Menurut Hammer \& Usry (1994), biaya produksi adalah penjumlahan dari tiga unsur biaya, yaitu biaya langsung, pekerja langsung, dan overhead pabrik. Biaya produksi merupakan biaya yang dikeluarkan untuk mengubah bahan mentah menjadi barang jadi melalui penggunaan tenaga kerja dan fasilitas pabrik. Horngren dan Foster (1992) juga menyatakan bahwa terdapat tiga unsur utama pada biaya produksi yakni biaya bahan baku (raw material), biaya tenaga kerja langsung dan tidak langsung (employee cost),dan biaya overhead (overhead cost). Nasution (2005) juga menyampaikan hal senada terkait 3 komponen utama pembentuk biaya produksi. Sedangkan keuntungan adalah semua pendapatan atau penghasilan akibat dari penjualan produk dan lebih besar dibandingkan biaya yang dikeluarkan (Supriyono, 1992). Untuk memaksimalkan keuntungan, perusahaan perlu membuat sebuah perencanaan produksi yang dapat memberikan keputusan optimal berdasarkan keterbatasan sumber daya yang dimiliki (Abbas dkk, 2008).

\section{METODE PENELITIAN}

Metode Penelitian yang digunakan adalah sebagai berikut : 1) Data yang digunakan sebagai alat pengukuran seperti data biaya produksi, harga jual, jam tenaga kerja dan penggunaan material merupakan data sekunder yang diperoleh dari perusahaan, 2) Teori yang digunakan untuk menunjang penelitian diperoleh melalui studi literatur baik dari Buku, Artikel yang pernah ditulis oleh peneliti lain, dan artikel dalam jurnal yang melakukan pembahasan sama, 3) Metode penyelesaian masalah menggunakan Pemrograman Linier sebagai tools dalam Riset Operasi.

\section{HASIL DAN PEMBAHASAN}

Berdasarkan uraian yang dikemukakan pada Bagian Pendahuluan, proses analisa memerlukan berbagai masukan data, antara lain : Data Harga Produksi (Tabel 1), Harga Jual (Tabel 1), Jam Tenaga Kerja (Tabel 2), dan Material (Tabel 3). 
Tabel 1. Daftar Komponen Biaya dan Harga Jual Setiap Tipe

\begin{tabular}{|l|c|c|c|c|c|}
\hline \multicolumn{1}{|c|}{ Jenis Lemari } & $\begin{array}{c}\text { Lemari 2 } \\
\text { Pintu Lebar }\end{array}$ & $\begin{array}{c}\text { Lemari 2 Pintu } \\
\text { Ramping }\end{array}$ & $\begin{array}{c}\text { Lemari 3 } \\
\text { Tingkat } \\
\text { Terbuka }\end{array}$ & $\begin{array}{c}\text { Lemari 3 } \\
\text { Tingkat } \\
\text { Terbuka } \\
\text { Ramping }\end{array}$ & $\begin{array}{c}\text { Lemari 1 } \\
\text { Tingkat } \\
\text { Tinggi }\end{array}$ \\
\cline { 2 - 5 } & $\mathrm{X} 1$ & $\mathrm{X} 2$ & $\mathrm{X} 3$ & $\mathrm{X} 4$ & $\mathrm{X} 5$ \\
\hline $\begin{array}{l}\text { Biaya Produksi/unit } \\
\text { (ribu) }\end{array}$ & 450 & 375 & 285 & 250 & 220 \\
\hline $\begin{array}{l}\text { Biaya Finishing } \\
\text { (ribu) }\end{array}$ & 125 & 125 & 85 & 85 & 50 \\
\hline $\begin{array}{l}\text { Biaya Cetak } \\
\text { Material (ribu) }\end{array}$ & 150 & 125 & 100 & 85 & 35 \\
\hline $\begin{array}{l}\text { Biaya Kemas/unit } \\
\text { (ribu) }\end{array}$ & 30 & 30 & 30 & 30 & 30 \\
\hline $\begin{array}{l}\text { Biaya } \\
\text { Operasional/unit } \\
\text { (ribu) }\end{array}$ & 100 & 90 & 100 & 90 & 80 \\
\hline $\begin{array}{l}\text { Harga Jual/unit } \\
\text { (ribu) }\end{array}$ & 2.100 & 1.800 & 1.350 & 1.150 & 950 \\
\hline
\end{tabular}

Sumber : Data Biaya Operasional Produksi Perusahaan

Tabel 2. Data Penggunaan Bahan Kayu

\begin{tabular}{|c|c|}
\hline Jenis Lemari & Bahan Baku Kayu (m3) \\
\hline Lemari 2 Pintu Pintu Lebar & 1.15 \\
\hline Lemari 2 Pintu Ramping & 0.98 \\
\hline Lemari 3 Tingkat Terbuka & 0.56 \\
\hline Lemari 3 Tingkat Terbuka Ramping & 0.40 \\
\hline Lemari 1 Tingkat Tinggi & 0.16 \\
\hline
\end{tabular}

Sumber : Data Perusahaan

Tabel 3. Jam Kerja Tenaga Kerja

\begin{tabular}{|c|c|}
\hline Jenis Lemari & $\begin{array}{c}\text { Waktu yang dibutuhkan untuk } \\
\text { menghasilkan 1 unit (jam/unit) }\end{array}$ \\
\hline Lemari 2 Pintu Pintu Lebar & 3.25 \\
\hline Lemari 2 Pintu Ramping & 2.82 \\
\hline Lemari 3 Tingkat Terbuka & 1.56 \\
\hline Lemari 3 Tingkat Terbuka Ramping & 1.23 \\
\hline Lemari 1 Tingkat Tinggi & 0.85 \\
\hline
\end{tabular}

Sumber : Data Perusahaan

Berikut juga merupakan persamaan dari Variabel Keputusan, Fungsi Tujuan, dan Fungsi Kendala :

Variabel Keputusan

1. $X_{1}=$ Lemari 2 Pintu Lebar

2. $X_{2}=$ Lemari 2 Pintu Ramping 
3. $\mathrm{X}_{3}=$ Lemari 3 Tingkat Terbuka

4. $\mathrm{X}_{4}=$ Lemari 3 Tingkat Terbuka Ramping

5. $\mathrm{X}_{5}=$ Lemari 1 Tingkat Tinggi

Fungsi Tujuan

Laba $=1245 X_{1}+1055 X_{2}+750 X_{3}+610 X_{4}+535 X_{5}$

Fungsi Kendala

Bahan Baku. 1.15 $\mathrm{X}_{1}+0.98 \mathrm{X}_{2}+0.56 \mathrm{X}_{3}+0.40 \mathrm{X}_{4}+0.16 \mathrm{X}_{5} \leq 376$

Jam Kerja. $\quad 3.25 X_{1}+2.82 X_{2}+1.56 X_{3}+1.23 X_{4}+0.85 X_{5} \leq 192$

Kuantitas. $\quad \mathrm{X}_{1} \geq 0$

$$
\begin{aligned}
& X_{2} \geq 0 \\
& X_{3} \geq 0 \\
& X_{4} \geq 0 \\
& X_{5} \geq 0
\end{aligned}
$$

Model-model persamaan diatas kemudian diolah menggunakan software WinQSB 2.0, sehingga kemudian diperoleh tabulasi data sebagai berikut.

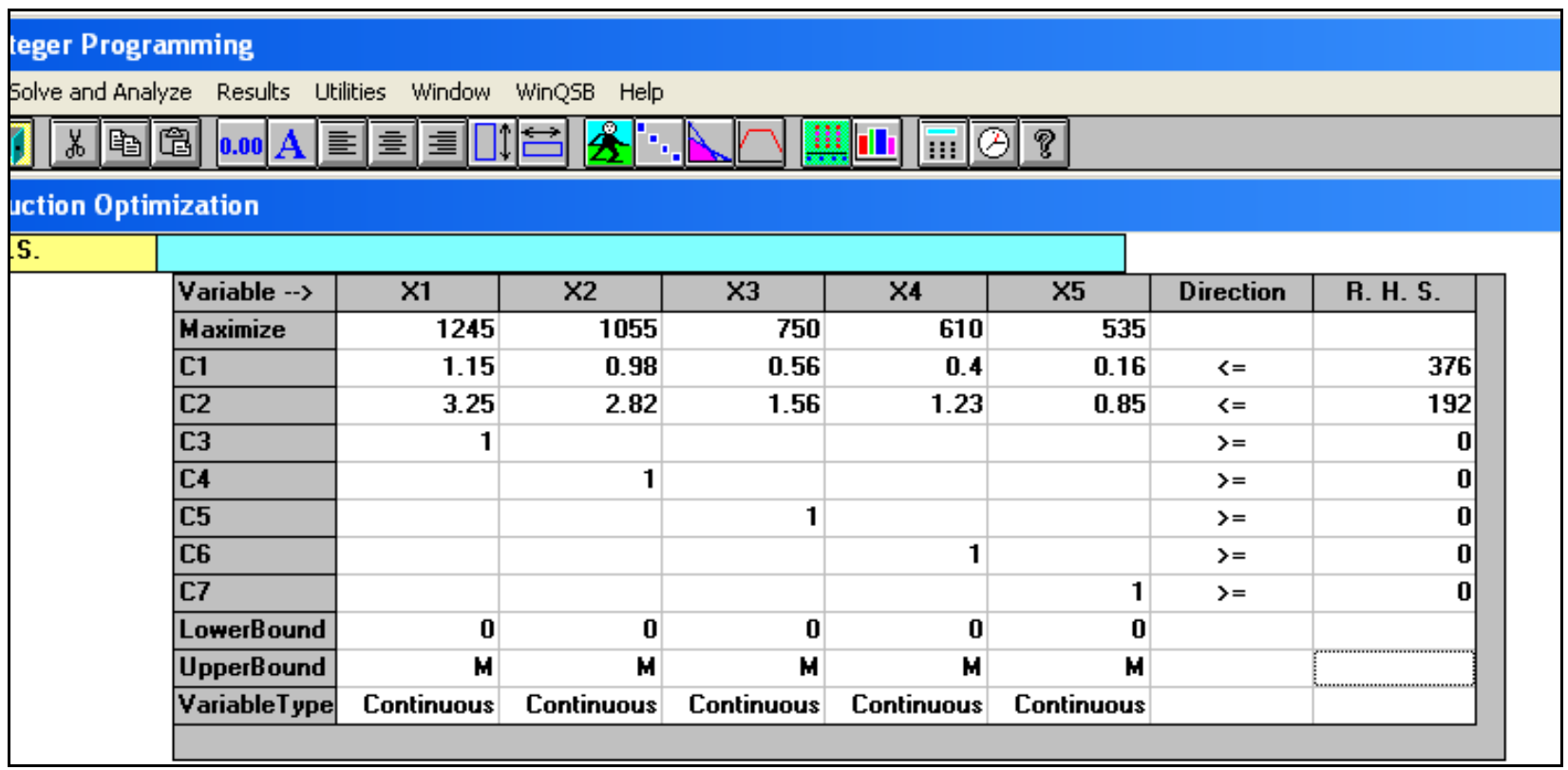

Gambar 1. Label Input Variabel dan Konstrain 


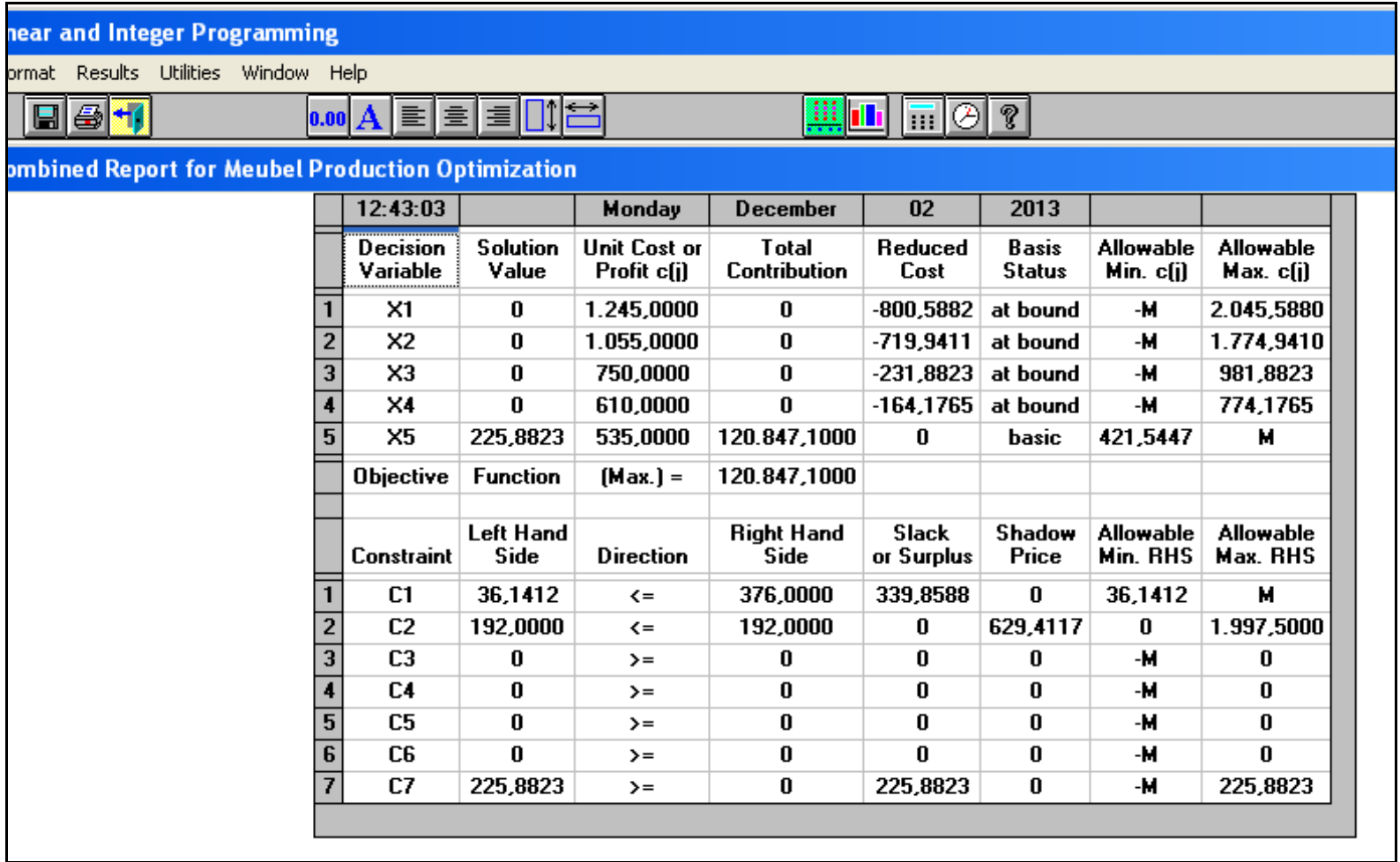

Gambar 2. Hasil Pengolahan Data dengan WinQSB 2.0

Berdasarkan hasil pengolahan data, diperoleh jumlah unit yang harus diproduksi sesuai dengan fungsi obyektif dari $Z_{\max }=1245 X_{1}+1055 X_{2}+750 X_{3}+610 X_{4}+535 X_{5}$ adalah :

1. $X_{1}$ (Lemari 2 Pintu Lebar) sebanyak 0 unit

2. $X_{2}$ (Lemari 2 Pintu Ramping) sebanyak 0 unit

3. $\mathrm{X}_{3}$ (Lemari 3 Tingkat Terbuka) sebanyak 0 unit

4. $\mathrm{X}_{4}$ (Lemari 3 Tingkat Terbuka Ramping) sebanyak 0 unit

5. $\mathrm{X}_{5}$ (Lemari 1 Tingkat Tinggi) sebanyak 255,8823 $\approx 225$ unit

Berdasarkan fungsi Obyektif diperoleh :

$$
\begin{aligned}
& Z_{\max } \quad=1245 X_{1}+1055 X_{2}+750 X_{3}+610 X_{4}+535 X_{5} \\
& =1245(0)+1055(0)+750(0)+610(0)+535(225) \\
& =120.847 .000
\end{aligned}
$$

Dari nilai $Z_{\max }$ diketahui bahwa keuntungan maksimum produksi akan diperoleh dengan menggunakan seluruh waktu produksi dan tenaga kerja yang ada untuk memproduksi Lemari 1 Tingkat Tinggi $\left(\mathrm{X}_{5}\right)$ yakni sejumlah 255 unit lemari. Berdasarkan keuntungan 
maksimum diketahui bahwa keuntungan maksimum $\mathrm{Z}_{\max }=$ Keuntungan yang diperoleh dari $100 \%$ produksi $\mathrm{X}_{5}$ yakni sebesar Rp 120.847.000. Penggunaan material kayu adalah sebesar $225\left(0.16 \mathrm{~m}^{3}\right)=36 \mathrm{~m}^{3}$ atau tidak melampaui fungsi persamaan penggunaan material $1.15 X_{1}+0.98 X_{2}+0.56 X_{3}+0.40 X_{4}+0.16 X_{5} \leq 376$. Sedangkan jumlah jam tenaga kerja dari keterbatasan fungsi persamaan $3.25 \mathrm{X}_{1}+2.82 \mathrm{X}_{2}+1.56 \mathrm{X}_{3}+1.23 \mathrm{X}_{4}+$ $0.85 \mathrm{X}_{5} \leq 192$, diperoleh sebesar $225(0.85)=191.25 \mathrm{jam}$.

\section{KESIMPULAN}

Sumber daya yang terbatas bukanlah faktor penghambat bagi perusahaan dalam mengoptimalkan keuntungan. Hasil penelitian membuktikan dengan keterbatasan material dan jumlah jam tenaga kerja, didapatkan rumusan jumlah produksi yang paling optimum bahkan memberikan kontribusi efisiensi sumber daya yang signifikan (dari $376 \mathrm{~m}^{3}$ haya terpakai $36 \mathrm{~m}^{3}$ ). Perlu juga dicermati bahwa dapat saja terjadi pergeseran nilai output produksi per type lemari apabila terjadi perubahan fungsi kendala. Pada penelitian apabila perusahaan memiliki keterbatasan jumlah jam tenaga kerja dan material seperti pada data yang dikemukakan, serta tidak terpengaruh dari hasil forecasting permintaan lemari, juga menggunakan tools WinQSB 2.0 maka akan diperoleh Keuntungan maksimum perusahaan adalah sebesar Rp 120.847.000 dengan total produksi yang dianjurkan hanyalah Lemari 1 Tingkat Tinggi sejumlah 225 unit lemari/192 jam kerja (1 bulan = 8 jam kerja).

\section{DAFTAR PUSTAKA}

Abbas B S, Robert. T. H, Shinta. 2008. Analisa Produksi Menggunakan Model Optimasi Linear Programming Pada PT.MAST. Jurnal Piranti Warta. Vol.11(3). Hal 469-482.

Abbas B S, Darudiato S, Fransisca. 2008. Sistem Informasi Optimalisasi Produksi Untuk Memaksimalkan Laba. Jurnal Piranti Warta. Vol.11(2). Hal 310-332.

Affandi P. 2011. Penerapan Program Linier Pada Permainan Non Kooperatif. Jurnal Matematika Murni dan Terapan. Vol.5(2). Hal 1-12.

Aminudin. 2005. Prinsip-Prinsip Riset Operasi. Jakarta : Erlangga.

Dimyati T T, Dimyati A. 1994. Operation Research. Bandung : PT. Sinar Baru Algesindo. 
Evans J B, Shelly F C, Stokes G H. 2003. Detection and Discovery of Near-Earth Asteroids by the Linear Program. Lincoln Laboratory Journal. Vol.14(2). Hal 199-220.

Hammer H L, Usry M F. 1994. Akuntansi Biaya Perencanaan dan Pengendalian. Edisi X. Jilid 1. Jakarta : Erlangga.

Horngren C T, Foster G. 1992. Akuntansi Biaya Suatu Pendekatan Manajerial. Edisi VI. Jilid 1. Jakarta : Erlangga.

Kumar A, Kaur J. 2011. A New Method for Solving Fuzzy Linear Programs with Trapezoidal Fuzzy Numbers. Journal of Fuzzy. Vol.2011. Hal 1-12.

Merlyana, Abbas B.S. 2008. Sistem Informasi Untuk Optimalisasi Produksi dan Maksimasi Keuntungan Menggunakan Metode Linear Programming. Jurnal Piranti Warta. Vol.11(3). Hal 370-387.

Mulyono S. 2007. Riset Operasi. Depok : Lembaga Penerbit Fakultas Ekonomi UI.

Nasution, Arman, Hakim. 2005. Manajemen Industri. Yogyakarta : Andi Offset.

Petrik M, Zilberstein S. 2011. Linear Dynamic Programs for Resource Management. Association for the Advancement of Artificial Intelligence (www.aaai.org).

Purnama, Fitri, Indah. 2010. Analisis Maksimalisasi Keuntungan di Industri Kecil Tahu Petis Lestari dengan Metode Simpleks. Tugas Akhir. Universitas Gunadarma. Jakarta.

Supriyono R A. 1992. Akuntansi Biaya Pengumpulan Biaya dan Penentuan Harga Pokok. Cetakan Pertama. Edisi II. Yogyakarta : BPFE.

Susanto S, Suryadi D, Adianto H, Aritonang K. 2006. Pemodelan Pemrograman Linier Dengan Koefisien Fungsi Obyektif Berbentuk Bilangan Kabur Segitiga dan Kendala Kabur Beserta Solusinya. Jurnal Teknik Industri. Vol.8(1). Hal 14-27.

Winston W L. 2003. Operation Research :Applications and Algorithms. Edisi 4. California : International Thompson Publishing. 